案中である。

演題26は「面濃度計の試作」と題して，血中ガス濃度 と胸部単純写真の肺野濃度との関係の報告である，胸部 $\mathrm{X}$ 線単純写真の濃度と相関関係を検討するため面濃度計 を試作したことに対して敬意を表わしたいと思う。結果 および考察の中でも述べられている通り，撮影条件から の胸部写真の藵度のバラツキ，ポジショニングが一定に できない.ICUは重篤な患者が多いためその日によって 呼吸のバラツキなどがあるため補正を加える方法を考え てもむずかしいように思われるが，今後の研究に期待し たいと思う。

最後にこのグループは装置・管理の研究発表であるがそれぞ れの演者らが身近な問題を解決し踟床に役立たせようとした 努力に対して敬意を表します.各演者ならびに最後まで聴講し て頂いた会場の方々に深謝致します。

\section{画像管理 I}

座長 細矢志郎（虎の門病院）

27. 多丹子反応型X線フィルム特性曲線の数式モテル I （数式モテルの成立過程）

東京都豊島区池装保健所 齊藤 誠

X線フィルムの感光から現象にいたる過程について， 感光銀粒子の相対増加率が

（1）未感光の銀粒子数に比例

(2) 簬光量に反比例

（3）銀粒子は反応の程度に応じていくつかの級に分類 できる

という仮定で次式を特性曲線の数式モデルとして導いた。

$$
D(H)=\frac{1}{k} \sum_{i=1}^{k} \frac{D_{\max }-D_{\min }}{1+(S i H)^{-c i}}+D_{\min }
$$

フィルム 30 種, 約 900 組のデータに対しての, 最小二乗 法によるあてはめ結果は, 残差の標準偏差が0.01以下の ものがほとんどあった。

28. 多分子反応型X線フィルム特性曲線の数式モデル II（各種フィルムへの適用）

昭和大学病院

○小田正記・中澤靖夫 東京都豊島区池袋保健所 薬藤 誠

X線記録系のセンシトメトリーに特性曲線の数式モデ ルを用いるためには，種々の特性をもったX線フィルム に対して，精度よく近似された特性曲線が描けなければ ならない。ここでは，現在市販されているX線フィルム を特性別に3種類に分け，多分子反応型数式モデルの適 用について特性曲線のあてはめの具合，計算結果等によ り検討を行った。
$\mathrm{X}$ 線フィルム30種類,特性曲線のデー夕約 900 個を用い て計算を行った結果，点対称に近い斜 S 字形の特性を示 すタイプのX線フィルムには 3 分子反応型, Lタイプ・ダ ブルガンマタイプのX線フィルムには，3 分子反応型を 用いることにより十分な適用性が認められた。

29. 多分子反応型X線フィルム特性曲線 III（センシト メトリーの手作業との比較)

東京都豊島区池袋保健所 ○䜞藤 諴 昭和大学病院 小田正記

$\mathrm{X}$ 線フィルムのセンシトメトリー（平均階調度, ガン マ値, 感度) について, 数式モデルによる計算值と手作 業によるものと比較した. 10 人の作業者に同一データ8 組を与え，個人差を調へたところ，最小でも0.1，最大で は0.74もあった。これは主に曲線の作成によって生じて いる。また同一作業者の結果もやはりバラツキがあった。 数式モデルを使用すると，このような個人差を解消す ることができる。

30. 多分子反応型X線フィルム特性曲線の数式モテル IV（反応型と精度）

昭和大学病院

○小田正記・中澤靖夫

東京都豊島区池袋保健所 齋藤 誠

数式モデルを用いて特性曲線の近似を行う場合, 測定 点を忠実にかつ滑らかに描くという意味では，2 分子反 応型より 3 分子反応型の数式モデルの方がすぐれている。 2 分子反応型で十分な精度の近似が行えるデータに 3 分 子反応型で近似を行った場合の問題点は，残差の標準偏 差が小さすぎ，測定誤差，実験精度の問題をもふくめて 計算され，階調度曲線が不自然な形になってしまうこと である。両反応型におけるセンシトメトリーに関する計 算結果の数値の相運は数\%とごくわずかであるが，精度 より見た反応型の選択という意味ではさらに検討が必要 である。

\section{座長集的}

このセクションの 4 題は，フィルム特性曲線の数式モ デルに関する一連の研究である。

今日のようにコンピュータが多用される時代, フィル 么特性曲線に限らず，放射線技術における諸現象を解析 し，数犆計算するため，数式モデルは増々有用になって くるであろう。

フィルム特性曲線の近似式は，今までラグランジェ補 間式, ニュートン差分商式，スブライン関数などが報告 されているが，この数式モデルがこれらの近似式と異る 点は，前者が現象を忠実に近似することのみを目的とす 